\title{
Kepemimpinan Etis pada Penerapan Strategi CSR dalam Perspektif Asta Brata
}

\author{
Ria Anindita ${ }^{1}$ \\ Fakultas Ekonomi dan Bisnis \\ Universitas Airlangga, Indonesia
}

\author{
Hamidah $^{2}$ \\ Fakultas Ekonomi dan Bisnis \\ Universitas Airlangga, Indonesia
}

Surel : ria.anindita-2018@feb.unair.ac.id

ABSTRAK

Pendekatan pemimpin pada program CSR memiliki hasil positif pada pencapaian loyalitas dan kepuasan pelanggan yang dapat mempengaruhi kinerja CSR. Tekanan publik yang lemah pada pelaporan CSR membuat pemimpin memahami pentingnya pengungkapan CSR didalam kebijakan perusahaan. Penelusuran nilai-nilai kepemimpinan etis dapat mengikuti ajaran nilai kepemimpinan Asta Brata. Nilai Asta Brata di dalam menggambarkan realitas CSR akan lebih mudah untuk dicerna dan dipelajari dengan menggunakan metafora, terutama bagi pihak yang tidak memilki pengalaman secara langsung. Nilai Asta Brata antara lain Mahambeg Mring Samudro, Mahambeg Mring Maruto, Mahambeg Mring Bhumi, Mahambeg Mring Angkasa, Mahambeg Mring Condro, Mahambeg Mring Dahana, Mahambeg Mring Suryo, dan Mahambeg Mring Kartika. Nilai tersebut merupakan nilai yang harus dimiliki pemimpin etis di dalam mempengaruhi karyawan menuju tujuan strategi CSR bersama. Nilai Asta Brata dapat menjawab fenomena program CSR namun hanya secara simbolis dan tidak memiliki unsur etis serta kepedulian pada masalah sosial dan masyarakat.

Kata Kunci: $\quad$ Kepemimpinan Etis; CSR; Asta Brata; Metafora.

\section{Ethical Leadership in the Implementation of CSR Strategies in Asta Brata's Perspective}

\section{ABSTRACT}

The leader's approach to the CSR program has positive results on achieving loyalty and customer satisfaction which can affect CSR performance. Weak public pressure on CSR reporting makes leaders understand the importance of CSR disclosure in company policy. The search for ethical leadership values can follow the teachings of Asta Brata's leadership values. The value of Asta Brata in describing the reality of CSR will be easier to digest and learn by using metaphors, especially for those who do not have direct experience. Asta Brata values include Mahambeg Mring Samudro, Mahambeg Mring Maruto, Mahambeg Mring Bhumi, Mahambeg Mring Angkasa, Mahambeg Mring Condro, Mahambeg Mring Dahana, Mahambeg Mring Suryo, and Mahambeg Mring Kartika. This value is the value that ethical leaders must have in influencing employees towards the goals of a shared CSR strategy. Value Asta Brata can answer the phenomenon of CSR programs but only symbolically and does not have ethical elements and concern for social and community issues.

Keywords: $\quad$ Ethical Leadership; CSR; Asta Brata; Metaphor.

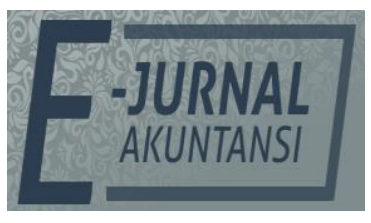

e-ISSN 2302-8556

Vol. 30 No. 10

Denpasar, Oktober 2020 Hal. 2698-2712

DOI:

10.24843/EJA.2020.v30.i10.p20

PENGUTIPAN:

Anindita, R. \& Hamidah. (2020). Kepemimpinan Etis pada Penerapan Strategi CSR dalam Perspektif Asta Brata.

E-Jurnal Akuntansi, 30(10), 2698-2712

RIWAYAT ARTIKEL: Artikel Masuk: 30 Juli 2020 Artikel Diterima: 5 Oktober 2020

Artikel dapat diakses : https://ojs.unud.ac.id/index.php/Akuntansi/index 


\section{PENDAHULUAN}

Corporate Social Responsibility merupakan program yang di lakukan perusahaan sebagai bentuk tanggung jawab sosial perusahaan. Pendekatan manajemen puncak untuk program CSR melalui pendekatan kolaboratif menunjukkan hasil positif di beberapa industri dalam mencapai loyalitas dan kepuasan pelanggan dapat memengaruhi kinerja dan menambah nilai. Pemimpin merupakan bagian internal perusahaan sehingga merupakan simbol dari budaya perusahaan. Kemampuan manajemen puncak untuk mengelola identitas perusahaan dipengaruhi oleh konteks budaya perusahaan. Budaya CSR adalah tanggung jawab etis perusahaan untuk dampak aktivitas bisnis pada masyarakat dan pemimpin dipercayakan dan diharapkan menciptakan budaya organisasi yang berpedoman pada nilai ,etis dan norma serta terintegrasi antar karyawan (Maulidiana, 2018) dan (Silvestri \& Veltri, 2020).

Penelitian ini akan membahas kepemimpinan etis manajemen puncak dalam menjalankan program CSR mengkaji dari sudut pandang filosofi kepemimpinan yang tergambar pada budaya lokal. Kepemimpinan berasal dari budaya Indonesia salah satu adalah kepemimpinan model Jawa Asta Brata. Ajaran Asta Brata bermula pada teks Jawa kuno Serat Nitisruti dan serat Pustakaraja Purwa. Nilai-nilai kepemimpinan mulai diterapakan pada masyarakat umum melalui kesenian Wayang dengan lakon Wahyu Makutha Rama. Ajaran Asta Brata terdapat delapan ajaran sifat dari dewa alam langit, matahari, angin, air, samudra, bulan, bintang, dan api dilain sumber menambankan sifat mendung dan air. Budaya Jawa memilki ciri khas menggunakan simbolisasi yang merupakan pengaruh ajaran agama Hindu dimasa lampau. Asta Brata berawal dari kitab Manawa Dharma Sastra yaitu kitab hukum Hindu yang ditulis dalam bahasa Sansekerta. Manawa Dharma Sastra dihimpun oleh Bhagawan Bhirgu yang diajarkan oleh Manu, pemuka agama Hindu. Kitab Manawa Dharma Sastra berisi ajaran kepemimpinan raja perlu berasaskan pada kedelapan sifat dewa. Sifat elemen alam menjadi sifat kepemimpinan merupakan penggambaran interaksi masyarakat Jawa dengan alam (Anggoro \& Virdanianty, 2015) dan (Rai \& Suarningsih, 2019). Penelitian sebelumnya mengenai Asta Brata dilakukan oleh Kobalen \& Bakti (2019) menjelaskan pemerintah dalam menjalankan GCG perlu mengamalkan ajaran Asta Brata untuk meningkatkan kesejahteraan masyarakat. Penelitian Selvarajah et al. (2017) dalam peningkatan kinerja perangkat desa maka perlu kepemimpinan dalam perspektif Asta Brata.

Perbedaan penting yang mencolok pengungkapan CSR di negara maju dan berkembang adalah terletak pada inisiatif pihak internal dan tekanan pihak eksternal . Negara maju dalam pengungkapan CSR dalam perhatian dan tekaan pemangku kepentingan seperti pemerintah, pemegang saham, kreditor, pencinta lingkungan, dan media dianggap sangat penting dalam mengungkapkan informasi CSR. Negara berkembang dalam pelaporan CSR dipengaruhi oleh kekuatan eksternal misalnya pembeli internasional, investor asing, keprihatinan media internasional, dan badan pengatur internasional seperti Bank Dunia. Negara berkembang hanya merasakan sedikit tekanan dari publik untuk pengungkapan CSR yang menunjukkan bahwa publik di negara berkembang kurang memiliki informasi tentang masalah sosial dan lingkungan dan membutuhkan program kesadaran yang menyoroti masalah sosial dan 
lingkungan. Tekanan publik yang lemah untuk pelaporan CSR menjadikan pemahaman manajemen puncak tentang pengungkapan CSR di negara-negara berkembang menjadi penting untuk kebijakan di setiap perusahaan. Perusaaan dan industri di negara-negara berkembang perlu menumbuhkan dan membudayakan kepemimpinan CSR sehingga secara positif mempengaruhi kinerja CSR, yang pada gilirannya dapat meningkatkan aspek-aspek lain dari kinerja perusahaan khususnya kepuasan pelanggan dan kinerja keuangan (Abernathy et al., 2017) dan (Silvestri \& Veltri, 2020).

Penelitian ini memiliki kebaharuan berupa penelusuran nilai-nilai kepemimpinan etis pada implementasi strategi CSR yang berlandaskan kepada ajaran sifat kepemimpinan Asta Brata. Gaya kepemimpinan etis pada manajemen puncak sangatlah penting untuk dikaji dan diperhatikan mengingat banyaknya CSR yang dijalani perusahaan saat ini sebatas menjalankan kewajiban perusahaan dengan membayar kerugian yang mengalami dampak terhadap kegiatan bisnis yang perusahaan lakukan tanpa adanya sistem keberlanjutan. Penelitian sebelumnya hanya berfokus pada karateristik seperti Ukuran perusahaan, profitabilitas tinggi, dan industri profil tinggi dapat mempengaruhi pengungkapan CSR (Galant \& Cadez, 2017) dan (Yuda, 2016). Faktor-faktor praktik, politik, sosial, dan budaya perlu diperhitungkan juga dalam pengambilan keputusan pengungkapan CSR. Penyelenggaran CSR bagi perusahaan menjadikan tambahan beban perusahaan dalam pengeluaran dana untuk menjalankan kewajiban etis. Penelitian ini memiliki perbedaan dengan penelitian-penelitian sebelumnya dimana pada penelitian sebelumnya membahas tentang faktor yang mempengaruhi tingkat pengungkapan informasi CSR dan penelitian sifat kepemimpinan Asta Brata dikaitkan dengan lingkungan sektor publik. Kepemimpinan dalam menanggulangi tanggung jawab sosial di luar sektor publik kurang menjadi prioritas karena berorientasi pada profit berbeda dengan pemimpin pemerintahan yang tugas utama adalah mensejahterakan masyarakat. Penelitian ini membahas tentang implementasi peran manajemen puncak dalam mengambil keputusan etis dalam strategi CSR. Pendekatan gaya kepemimpinan etis pada pengambilan keputusan menggunakan pertimbangan norma etis yang menguntungkan pihak perusahaan dan masyarakat serta menjalin komunikasi dan kebersamaan antar tim (Gea, 2014) dan (Hemingway \& Starkey, 2018).

Tujuan dari penelitian ini adalah menafsirkan sifat kepemimpinan Asta Brata dengan kesesuaian konsep gaya kepemimpinan dalam menentukan strategi CSR. Pemaknaan konsep ini diharapkan setiap perusahaan perlu mempertimbangkan sikap etis dan norma yang berlaku pada kebudayaan masyarakat saat membuat kebijakan strategi CSR. Penafsiran teks konteks yang lebih luas atas gaya kepemimpinan etis berdasarkan perspektif Asta Brata membantu setiap perusahaan memenuhi kewajiban pertanggungjawaban berdasarkan unsur etis. Kontribusi penelitian bagi dunia akademisi adalah menghasilkan wawasan baru pada penelitian karakter manusia mengenai kepedulian sebagai makluk sosial kepada masyarakat sesuai ajaran Asta Brata. Kontribusi praktis pada penelitian ini adalah dengan memaknai konsep Asta Brata terhadap implementasi gaya kepemimpinan etis terhadap kebijakan strategi CSR yang dilakukan oleh perusahaan memiliki nilai dan norma hubungan sosial terhadap masyarakat 
yang secara tidak langsung dapat meningkatkan keberlangsungan hidup perusahaan.

\section{METODE PENELITIAN}

Analisis metafora memungkinkan para peneliti untuk mengerti dan melaporkan fenomena sosial dengan cara yang menarik. Analisis metafora berguna untuk mengungkap makna yang tersembunyi dan menyelidiki asumsi-asumsi melalui penelusuran pendukung untuk diberikan kepada kelompok-kelompok yang mengalami kesulitan pemahaman. Penggunaan metafora memungkinkan para peneliti untuk memiliki pandangan luas. Peneliti dapat menyelidiki asumsi dan norma untuk merefleksikan secara kritis mengenai pengalaman mengenai suatu hal. Pendekatan analisis metafora juga bekerja dengan populasi yang tidak dapat mengartikulasikan pengalaman mereka dengan jelas (Haula \& Nur, 2018) dan (Sahib, 2016).

Analisis metafora berguna untuk mengungkap makna yang tersembunyi dan menyelidiki asumsi-asumsi melalui penelusuran pendukung untuk diberikan kepada kelompok-kelompok yang mengalami kesulitan pemahaman (Hemingway \& Starkey, 2018) dan (Kalbarini \& Suprayogi, 2014). Proses menginterpretasikan teks menempatkan kembali penjelasan dan interpretasi dengan konsep umum. Konsep tersebut harus menyatukan antara penjelasan dan pemahaman pada saat pembacaan teks untuk menghasilkan makna yang saling berhubungan. Analisis penelitian ini mengikuti teori metafora konseptual yang dikemukakan oleh (Lakoff \& Jhonson 1980).

Penemuan fakta pendukung intepretasi dengan cara mempertimbangkan semua aspek yang berhubungan antara Asta Brata pada CSR. Kondisi pemahaman secara umum hasil dari pemahaman akuntasi lingkungan dengan menghubungan antara keberakhiran dan universalitas, dan antara teori dan praktik (Kövecses, 2017) dan (Perrez \& Reuchamps, 2015). Konsep metafora dalam konteks penilaian melibatkan proses penalaran secara akal pikiran melalui kegiatan individu secara sosial membangun makna dan ide melalui bahasa yang sangat bergantung pada konsep yang berasal dari kehidupan nyata. Metafora sebagai alat yang tepat untuk penggambaran realitas CSR perusahaan sebagai realitas dari pengalaman mereka dalam aktivitas bisnis dijabarkan secara lebih mudah untuk dicerna dan dipelajari bagi pihak yang tidak memilki pengalaman secara langsung dengan memetaforakan sifat alam pada Asta Brata (Sahib, 2016).

Realitas CSR perusahaan dan Asta Brata didapat penulis menggunakan studi literatur yang membahas pengalaman umum perusahaan dalam menjalankan CSR.Studi literatur memberikan asumsi- asumsi teori pendukung untuk menjelaskan nilai mana saja yang ada di Asta Brata yang dapat memperjelas keberadaan strategi CSR. Penggunaan studi literatur dari berbagai penelitian terdahulu berguna untuk memudahkan memetakan nilai-nilai yang terkandung tentang Asta Brata di kehidupan masyarakat Indonesia. Proses analisis selanjutnya menggunakan metafora untuk menjelaskan bahasa tersirat pada Asta Brata dengan realitas pengalaman pembuatan strategi CSR sesuai nilai yang terkandung (Ratna, 2019). Fungsi nyata Asta Brata dalam kehidupan di masa sekarang didukung dengan wawancara dua informan yaitu Pak Iwan sebagai manajer cabang sebuah gerai kopi dan Pak Hendra sebagai manajer sebuah 
perusahaan air mineral yang memiliki kerjasama dengan perusahaan biji plastik yang berasal dari sistem daur ulang.

Penelitian ini digunakan untuk memahami kepempinan Asta Brata yang berkaitan dengan CSR. Peran metafora pada pembahasan selajutnya adalah menyampaikan pemahaman kepemimpinan etis dalam Asta Brata yang berhubungan dengan peran pemimpin dalam menjalankan CSR yang merupakan tanggung jawab moril perusahaan. Penelitian ini tersusun untuk menemukan pemanfaatan dan keuntungan yang berasaskan pada pendekatan pada Asta Brata perlu mendapatkan pemahaman dalam karya akan budaya Jawa yang bersumber pada teks dengan bahasa yang khusus perlu di amati secara mendalam (Anggoro \& Virdanianty, 2015) dan (Selvarajah et al., 2017).

\section{HASIL DAN PEMBAHASAN}

Kemampuan manajemen secara pengalaman dan akademisis sangat penting tetapi kebutuhan untuk pemimpin yang memiliki kepemimpinan otentik dan etis lebih diutamakan. Persyaratan kuat untuk kinerja perusahaan yang berkelanjutan dapat tercapai ketika pendekatan tersebut tertanam dalam bisnis inti. Pemimpin CSR yang menekankan kejujuran, keterbukaan dan integritas dapat menerapkan konsep penciptaan nilai melalui budaya CSR yang kuat. Kegiatan CSR dapat dikatakan berhasil apabila mendapat dukungan dan kesadaran dari tim manajemen puncak perusahaan yang menjadi dasar pelaksanaan program. Kesadaran dan dukungan tim manajemen puncak terlihat pada pembuatan kebijakan yang peduli dengan lingkungan sosial dan mengatur sumber daya yang dimiliki perusahaan untuk menuju tujuan kesejahteraan bersama antara perusahaan dan masyarakat (Nejati et al., 2019) dan (Setiyadi \& Rasmini, 2016).

Teori Kontrak Sosial (Rokhlinasari, 2016) dan (Wijaya, 2016) menyatakan bahwa perlu dibutuhkan interelasi di kehidupan sosial untuk menimbulkan keselarasan, keserasian, dan keseimbangan antara perusahaan dan masyarakat dengan membentuk kontrak sosial. Kontrak sosial bertujuan untuk menerangkan hubungan antara perusahaan terhadap masyarakat untuk melindungi kepentingan dari setiap pihak. Program CSR dilakukan untuk menjalin hubungan antara perusahaan dengan masyarakat dalam hal memenuhi dan mematuhi aturan serta norma-norma pada semua kegiatan yang dilakukan perusahaan dengan tujuan menguntungkan semua pihak. Program CSR berjalan dengan baik memiliki keuntungan bagi kelangsungan bisnis perusahaan sesuai pada konsep teori legitimasi Suchman, (1995) yaitu keberadaan perusahaan tidak menganggu dan sesuai dengan budaya dan nilai dalam masyarakat akan menjamin kelangsungan hidup perusahaan.

Kepemipinan etis adalah gabungan dari kecakapan dan karakter budi perkerti seperti karisma dalam mempengaruhi, menyakinkan dan memimbing karyawan yang dipimpinnya untuk menjalankan tugas kerja secara ikhlas dan sukarela. Kekuatan tim yang solid akan menuju kesuksesan tujuan perusahaan bersama. Kepemimpinan etis merupakan landasan suatu manajemen, sedangkan pokok dari kepemimpinan adalah interaksi antar anggota. Pendekatan analisis kepemimpinan didominasi pada teori general psychology. Pendekatan general psychology mempunyai sekat budaya berakar dari tradisi budaya Barat sehingga 
menimbulkan pertentangan situasi dengan budaya Timur. Penelitian mengkaji dari perspektif filosofi kepemimpinan dari budaya lokal (Nejati et al., 2019) dan (Setiyadi \& Rasmini, 2016).

Pola kepemimpinan yang mengaplikasikan nilai-nilai kearifan lokal akan lebih mudah dalam memperoleh dan menempatkan diri terhadap setiap pergeseran dan kesinambungan jaman. Pola kepemimpinan yang menyebar pada masa sekarang diselaraskan dengan nilai kepemimpinan bangsa Indonseia, sehingga proses kepemimpinan dapat berjalan dengan baik. Budaya local yang mengusung kepemimpinan etis terdapat pada ajaran Asta Brata.

Konsep Asta Brata merupakan konsep yang penjabaranya berasaskan sifat dewa atau alam semesta. Sifat kepemimpinan etis dijelaskan dalam metafora sifat Asta Brata agar mudah dipahami karena sifat alam merupakan hal yang sering dijumpai masyrakat umum. Penjabaran mengenai kepemimpinan etis dengan perspektif Asta Brata terdapat pada tabel 1.

Tabel 1. Matrik Kepemimpinan Etis dalam Perspektif Asta Brata

\begin{tabular}{|c|c|c|c|}
\hline $\begin{array}{c}\text { Unsur Pokok } \\
\text { Kepemimpinan Etis }\end{array}$ & Asta Brata & $\begin{array}{l}\text { Sifat } \\
\text { Alam }\end{array}$ & Makna \\
\hline $\begin{array}{l}\text { Kepemimpan perlu } \\
\text { melibatkan orang lain } \\
\text { dengan saling }\end{array}$ & $\begin{array}{l}\text { Mahambeg Mring } \\
\text { Samudro }\end{array}$ & Samudra & $\begin{array}{l}\text { Mampu menampung } \\
\text { aspirasi, bijak mengambil } \\
\text { keputusan }\end{array}$ \\
\hline $\begin{array}{l}\text { berinteraksi sesama } \\
\text { anggota }\end{array}$ & $\begin{array}{l}\text { Mahambeg Mring } \\
\text { Maruto }\end{array}$ & Angin & $\begin{array}{l}\text { Ada dimana-mana tanpa } \\
\text { menunjukan kedatangannya, } \\
\text { Mengetahui kondisi } \\
\text { sebenarnya }\end{array}$ \\
\hline \multirow[t]{2}{*}{ Memiliki kemampuan } & $\begin{array}{l}\text { Mahambeg Mring } \\
\text { Bhumi }\end{array}$ & Bumi & Kuat, pemaaf, ikhlas \\
\hline & $\begin{array}{l}\text { Mahambeg Mring } \\
\text { Angkasa }\end{array}$ & Langit & $\begin{array}{l}\text { Tulus, mampu } \\
\text { mengendalikan diri, luas } \\
\text { pengetahuan }\end{array}$ \\
\hline \multirow[t]{2}{*}{$\begin{array}{l}\text { Adanya cara } \\
\text { mempengaruhi } \\
\text { karyawan }\end{array}$} & $\begin{array}{l}\text { Mahambeg Mring } \\
\text { Condro }\end{array}$ & Bulan & $\begin{array}{l}\text { Menerangi tanpa } \\
\text { menyilaukan, sifat teduh, } \\
\text { nyaman, lembut }\end{array}$ \\
\hline & $\begin{array}{l}\text { Mahambeg Mring } \\
\text { Dahana }\end{array}$ & Api & $\begin{array}{l}\text { Memberi semangat, } \\
\text { kehangatan, kehidupan }\end{array}$ \\
\hline \multirow[t]{2}{*}{$\begin{array}{l}\text { Adanya pencapaian visi } \\
\text { bersama }\end{array}$} & $\begin{array}{l}\text { Mahambeg Mring } \\
\text { Suryo }\end{array}$ & Matahari & $\begin{array}{l}\text { Pemberi semangat, adil, } \\
\text { berkerjasama }\end{array}$ \\
\hline & $\begin{array}{l}\text { Mahambeg Mring } \\
\text { Kartika }\end{array}$ & Bintang & $\begin{array}{l}\text { Setia pada tempatnya, } \\
\text { konsisten dan teguh }\end{array}$ \\
\hline
\end{tabular}

Sumber: (Anggoro \& Virdanianty, 2015), (Gea, 2014), dan (Rai \& Suarningsih, 2019)

Metafora sifat Samudra dan anging dalam melibatkan orang lain dengan saling berinteraksi sesama anggota. Mahambeg Mring Samudro . Samudra mempunyai karakteristik sebagai kumpulan lautan luas yang berbentuk cekungan besar. Sifat Samudra di metafora sebagai sosok pemimpin dengan kemampuan pengetahuan luas seperti kumpulan laut yang tertampung dari berbagai arah. Mahambeg Mring Maruto. Karakteristik sifat angin mampu menerobos pada sela-sela penjuru sampai terkecil. Bentuk angin tidak dapat dilihat melainkan dapat dirasakan dan dibutuhkan keberadaan. Sifat angin di metaforakan pada pemimpin harus mampu menguasi semua keadaan di 
perusahaan dan dekat dengan karyawan (Anggoro \& Virdanianty, 2015) dan (Rai \& Suarningsih, 2019).

Karakteristik tim manajemen puncak yang berbeda juga menimbulkan perbedaan tingkatan kepedulian pada kebijakan strategi CSR. Gaya kepemimpinan pada tim manajemen puncak penting untuk dikaji lebih mendalam karena gaya kepemimpinan dengan mengandalkan sifat samudra dapat menjadikan pemimpin menjalin kedekatan dengan karyawan. Kedekatan antara tim manajemen puncak dengan karyawan menumbuhkan komitmen bekerja yang sadar mengenai hak dan kewajiban di perusahaan dalam strategi CSR sesuai keinginan pimpinan untuk mencapai tujuan. Keberhasilan kebijakan strategi CSR yang dibuat oleh tim manajemen puncak merupakan hasil kerjasama dan partisipasi antara semua anggota perusahaan. Terjalin komunikasi yang baik antara manajemen puncak dengan tingkatan manajemen yang lain akan menimbulkan kenyamanan dan kesadaran tanggung jawab peran bagi karyawan. Komunikasi yang baik meningkatkan kebersamaan sehingga pondasi tim kuat dalam menjalankan tugas pokok secara sungguh-sungguh dan meningkatkan komitmen untuk bekerja secara tim. Sifat angin menunjukan keberadaan pemimpin dan kondisi seluk beluk perusahaan terjadi dengan pondasi tim yang kuat. Tanpa kehadiran pemimpin, karyawan juga tetap menjalankan tugas. Kepemimpinan merupakan kualitas pribadi dan bukan posisi hierarkis. Masalah etika adalah masalah kepemimpinan karena kepemimpinan tidak ditentukan secara sosial tetapi secara pribadi dan psikologis, setiap orang dapat berusaha untuk menjadi seorang pemimpin melalui peningkatan kesadaran diri seseorang secara terus-menerus (Rai \& Suarningsih, 2019) dan (Setiyadi \& Rasmini, 2016).

Hasil wawancara dengan informan mengenai kepedulian manajemen puncak pada kebijakan strategi memang penting terutama bagi manajamen puncak dari kantor cabang seperti Bapak Iwan yang memiliki kewajiban menjalankan SOP CSR yang telah dibuat oleh kantor pusat untuk dijalankan dengan baik untuk seluruh karyawan cabang yang menjadi tanggung jawab dari beliau. Bapak Iwan menjelaskan.

"Kami sebagai kedai kopi cabang memiliki implementasi CSR dalam dua bentuk yaitu CSR dalam skala kecil yang kami rancang sendiri lalu kami membuatkan proposal pengajuan dana kepada pusat dan CSR dalam skala besar yang dibuat oleh kantor pusat untuk dilaksanakan pada setiap kantor cabang. Komunikasi menjadi dua arah yaitu kepada pihak pusat dan karyawan cabang. Sebagai kepala cabang saya dituntut untuk mengevaluasi dan monitoring aspek lokalitas guna memastikan kesesuain proses dan capaian sesuai rencana atau tidak dan Evaluasi bermanfaat bagi rencana pelaksanaan program yang sama diwaktu dan tempat lainnya. Contoh program konservasi air untuk pembuatan minuman serta untuk mencuci peralatan. Tiap gerai dituntut inovasi dan kreatif dalam menjaga dan menggunakan alat penyulingan dalam memenuhi air bersih untuk produksi yang setiap cabang akan memiliki kendala yang berbeda disetiap gerai."

Kepemimpinan bukan tentang membedakan antara yang baik dan yang buruk, tetapi tentang membuat pilihan sebagai tindakan diinginkan dan yang tidak diinginkan, sesuai dengan prinsip atau nilai yang lebih tinggi. Sifat angin yang dapat menembus ruang kecil menjadikan kehidupan organisasi 
menghadirkan tantangan bagi pemimpin. Tidak hanya pemimpin yang harus memimpin secara emosional tetapi mereka yang dipimpin dapat menjadi objek mekanis. Pemimpin dengan sifat angin perlu menjadikan posisi tersebut menguasai seluk beluk perusahaan dengan bersinergi bersama karyawan. Tujuan ekonomi yang logis, nyata dan terukur dapat menghilangkan pemimpin yang emosional, kegiatan CSR membantu dengan membawa dimensi emosional. CSR mengundang siapa pun yang dapat berhubungan dengan organisasi untuk bertindak sebagai cermin sukarela yang mencerminkan bagaimana kegiatan strategis perusahaan dapat memiliki makna emosional yang akan memungkinkan organisasi untuk bertindak dengan cara menipu diri sendiri dan tidak etis. Oleh karena itu, CSR tidak mengadu organisasi dengan masyarakat juga tidak menjadi kewajiban atau kendala bukannya manfaat karena tidak terintegrasi ke dalam atau bersaing dengan strategi bisnis organisasi (Karaosmanoglu et al., 2016) dan (Reimer et al., 2018).

Metafora sifat bumi dan langit dalam Kemampuan yang dimiliki pemimpin. Mahambeg Mring Bhumi. Karakteristik sifat bumi tumpuan dan sanggup menyuguhkan kehidupan untuk rakyatnya. Kekayaan di bumi diberikan secara percuma dan menghasilkan sesuatu yang berguna bagi kehidupan manusia. Sifat bumi dimetaforakan sebagai pemimpin yang dapat menaungi dan menjaga karyawan. Mahambeg Mring Angkasa. Karateristik Langit yaitu luas tak terbatas, hingga mampu menampung pengetahuan apa saja yang datang padanya. Seorang pemimpin dimetaforakan sebagai langit harus berwibawa, memberikan kesejahteraan, dan menggetarkan bagi siapa saja yang akan dan telah berbuat salah melanggar peraturan. Ia memilki kemampuan beradaptasi dengan menempatkan diri sesuai dengan wadahnya, ia selalu merendah dan mampu mengisi setiap celah. Seorang pemimpin harus mempunyai kemampuan untuk menyesuaikan dan bersedia menerima pendapat dari bawahan dan memikirkan baik-baik semua pendapat yang ada (Anggoro \& Virdanianty, 2015) dan (Rai \& Suarningsih, 2019).

Hasil wawancara dengan informan mengenai kepedulian manajemen puncak pada ketaatan mitra bisnis dalam menjalankan kebijakan strategi memang penting seperti Bapak Hendra yang memiliki tugas memantau mitra bisnis yang bekerjasama dengan perusahaannya untuk mengolah botol plastik daur ulang sebagai bentuk kepedulian lingkungan CSR agar mengurangi sampah plastik. Pak Hendra memantau agar mitra bisnis menjalankan SOP daur ulang plastik yang telah dibuat oleh perusahaanya. Bapak Hendra menjelaskan

"Perusahaan kami memiliki program CSR dalam bijak berplastik, kami memiliki SOP untuk menggunakan biji plastik yang berasal dari daur ulang. Pengolahan dan pengumpulan botol bekas kami serahkan pada pihak mitra bisnis kami, mitra bisnis kami dapatkan melalui tender dengan mengajukan persyaratan meski daur ulang, faktor higienis tetap diutamakan. Kami pihak yang berkerjasama dengan mitra tidak segan memberi sanksi apabila SOP yang kami minta tidak dijalankan dengan baik. Kesalahan dalam proses pendaur ulang plastic akan berdampak besar bagi perusahaan kami. Tiap 6 bulan sekali kami mengunjungi pabrik milik mitra bisnis untuk melihat proses daur ulang"

Manajemen puncak memiliki fungsi utama yaitu membuat suatu kebijakan. Kebijakan bertujuan untuk mengarahkan personil perusahaan secara 
menyeluruh untuk mematuhi dan peduli pada suatu hal dalam menjalankan aktivitas perusahaan. Kebijakan yang dibuat manajemen puncak memilki tanggung jawab besar apabila kebijakan tersebut mengandung pelanggaran norma dan tidak etis untuk dilakukan maka keseluruhan karyawan akan terbawa dalam pelanggaran norma dan ketidak etisan tersebut dalan melakukan aktivitas perusahaan. Kinerja yang dihasilkan dari kebijakan tersebut juga mempengaruhi komptensi dan integritas suatu individu bahkan keseluruhan perusahaan. Sifat bumi untuk menjaga integritas karyawan dan reputasi perusahaan membuat pemimpin memberi contoh untuk selalu membuat kebijakan etis dapat mensejahterakan karyawan secara tidak langsung. Kebijakan yang sesuai norma menjadikan cermin kepribadian seorang pemimpin seperti sifat langit yang mampu mengendalikan diri. Kepribadian pemimpin yang disegani karyawan akan menimbulkan empati yang lebih untuk pemimpin (Hur et al., 2018) dan (Koten, 2016).

Pemimpin memiliki sikap terbuka dan mampu menampung aspirasi dari para bawahannya. Pemimpin hendaknya bersikap bijak dalam menyikapi setiap kritik dari bawahan. Gaya Kepemimpinan etis perlu dijadikan pedoman bagi manajemen puncak karena gaya kepemimpinan ini fokus dan wajib mempertimbangkan nilai dan sikap etis dalam pengambilan keputusan untuk membuat kebijakan. Kebijakan perusahaan dalam pengembangan bisnis apabila memiliki kepemimpinan etis dengan bersumber wawasan yang luas maka kebijakan tersebut tidak murni demi kepentingan perusahaan sendiri melainkan mempertimbangkan pihak lain diluar perusahaan seperti kesejahteraan masyarakat sekitar dan keramahan lingkungan alam. Pelaksanaan CSR bertujuan untuk memenuhi kewajiban perusahaan sebagai wujud tulus dan terimakasih bahwa profit besar yang diterima merupakan kerjasama antara karyawan yang telah menunjukkan kesungguhan dalam bekerja dan dukungan masyarakat sekitar dalam kelangsungan bisnis perusahaan (Lee-Davies, 2018) dan (Setiyadi \& Rasmini, 2016).

Metafora sifat bulan dan api dalam proses mempengaruhi bawahan. Mahambeg Mring Condro. Karakteristik cahya rembulan yaitu menerangi akan tetapi tidak memancarkan panas. Sifat Bulan mampu menyinari kala malam datang. Pemimpin dimetaforakan sebagai cahaya bulan dengan sosok penerang dan pemberi solusi disaat karyawan merasa gelap atau kesusahan. Pemimpin mampu memberikan motivasi kepada para bawahan agar performa kinerjanya meningkat. Mahambeg Mring Dahana Karakteristik api yaitu menerangi gelap sekaligus memberi kehangatan dan membara. Pemimpin dimetaforakan sebagai api selalu mampu memberi semangat membara pada karyawan untuk menyelesaikan masalah. Seorang pemimpin hendaknya berwibawa dan harus bisa menegakkan kebenaran dan keadilan secara tegas dan tuntas tanpa pandang bulu. Seorang pemimpin yang menguasai sifat Api adalah ia yang cekatan dan tuntas dalam menyelesaikan persoalan. Juga selalu konsisten dan objektif dalam menegakkan aturan, tegas, tidak pandang bulu dan objektif, serta tidak memihak (Anggoro \& Virdanianty, 2015) dan (Rai \& Suarningsih, 2019).

Menjalankan CSR bagi pak Iwan dan pak Hendra tidak mungkin tanpa kendala. Manajer cabang pak Iwan memiliki harus memastikan karyawan di 
training dengan baik. Pemilihan mitra bisnis yang dipercaya membutuhkan proses yang panjang.

Hasil wawancara dengan pak Iwan mengatakan bahwa "training karyawan pada kedai kami wajib dilakukan selain untuk pelayanan yang ramah pada pelanggan. Penggunaan alat di kedai kami memerlukan keahlian khusus. Alat penyuling air dan alat cuci peralatan yang menggunakan sedikit air bertujuan untuk tidak boros dengan air bersih yang semakin langka, hal tersebut juga merupakan upaya CSR kami dalam konversi air bersih. Apabila penggunaan alat tersebut sembarangan sehingga menimbulkan kerusakan, teknisi yang memperbaiki merupakan mitra khusus dari perusahaan pusat yang prosedur pengajuan akan lebih rumit dibanding memanggil teknisi biasa. Sebagai manajer gerai cabang, saya meminimalisir hal tersebut, penjagaaan dan monitoring karyawan lebih saya utamakan"

Hasil wawancara dengan pak Hendra mengatakan "mendapatkan mitra bisnis yang dapat dipercaya memiliki kendala dan persoalan yang panjang. Mitra bisnis merupakan bagian dari kita, cerminan dari kredibilitas kita. Pengajuan sebagai mitra bisnis dalam perusahaan kami memiliki standar minimal prosedur pengerjaan seperti sertifikat ISO. Kerjasama yang kompak juga dibutuhkan, kami ingin menjadi mitra bisnis yang saling symbiosis mutualisme. Saling membutuhkan akan menimbulkan kepercayaan dan etos kerja yang baik."

CSR perusahaan juga melibatkan kegiatan CSR internal yaitu dengan mendukung dan merawat kesejahteraan dan kebahagiaan karyawan dalam organisasi, yang semakin memperkuat karyawan persepsi rasa hormat dan status dalam organisasi, akhirnya mengarah ke perilaku peduli dan membantu untuk satu lainnya dalam organisasi sesuai sifat sinar bulan dan api yang bertujan menyinari. Karyawan dalam suatu perusahaan menghasilkan emosi yang positif pada saat bekerja yang mendorong mereka untuk membuka pikiran mereka untuk kemungkinan dan pembelajaran baru, yang menghasilkan keterbukaan kognitif dan peningkatan pemecahan masalah secara kreatif. Keterbukaan kognitif dan emosional yang lebih besar dan signifikan akan cenderung untuk merubah perilaku. Penelitan menyatakan bahwa semakin berpengalaman karyawan, semakin mereka saling melayani kepentingan diri sendiri. Kepedulian di tempat kerja membentuk konteks kerja yang membantu karyawan membuka diri terhadap berbagai ide yang menantang kompleksitas yang akhirnya menimbulkan kreativitas. Menghindari sifat individualis maka pemimimpin harus mampu mempengaruhi karyawan dengan pendekatan yang nyaman kepada karyawan (Phillips et al., 2019), (Silvestri \& Veltri, 2020), dan (Waniak-Michalak et al., 2016).

Pemimpin seperti CEO dan manajer senior harus membangun lingkungan kerja yang mempertimbangkan aspek persepsi subyektif terhadao karyawan tentang perusahaan mereka yaitu persepsi mengenai CSR dan pengalaman aktual mereka dalam suatu organisasi. Motivasi internal untuk meningkatkan kreativitas berkenaan dengan pengaruh signifikan persepsi CSR karyawan. Kreativitas karyawan didukung dengan kepedulian dan motivasi secara empiris menunjukkan bahwa sejauh mana karyawan mengalami kepedulian di tempat kerja dan jenis motivasi mereka mungkin menjadi titik pemeriksaan penting bagi mendeteksi kreativitas karyawan. Investasi sebuah organisasi dalam masyarakat 
meningkatkan rasa kreativitas karyawan untuk terlibat dalam kegiatan CSR cenderung karena alasan penting seperti memulihkan citra dan reputasi perusahaan yang rusak. Perusahaan dalam kegiatan CSR sebagai sarana untuk menciptakan kesan yang baik dengan publik melalui media (Reimer et al., 2018) dan (Wibowo et al., 2016).

Metafora sifat matahari dan bintang sebagai adanya tujuan bersama yang harus dicapai. Mahambeg Mring Suryo. Karakteristik matahari adalah memberi energi kepada alam semesta, menerangi kegelapan dan selalu siap sedia setiap hari untuk membantu segala aktivitas makhluk. Seorang pemimpin dimetaforakan dengan sifat Matahari diharapkan menjadikan sosok inspirasi dan pemberi semangat kepada karyawan untuk menyelesaikan segala persoalan yang dihadapi. Pemimpin bertugas memberikan semangat dengan energi positif kepada para karyawan dengan tingkatan hati-hati yang tinggi secara tidak langsung akan membawa tujuan perusahaan dengan bersama-sama. Mahambeg Mring Kartika Karakteristik bintang menjadikan sebagai penunjuk arah dan tersebar di seluruh penjuru tanpa tergantung dengan grafitasi matahari. Pemimpin dimetaforakan sebagai sifat bintang maka pemimpin sebagai penunjuk arah perusahaan dan teguh dan bertanggung jawab atas keputusan yang diambil. Sifat tegas dalam menegakkan hukum tidak pandang bulu untuk membela kebenaran maupun membela karyawan. Pemimpin memiliki sifat percaya diri dalam memegang teguh prinsip yang diyakini sebagai pedoman penunjuk arah bagi karyawan dalam bekerjasama mencapai tujuan (Anggoro \& Virdanianty, 2015) dan (Rai \& Suarningsih, 2019).

Masalah kredibilitas mendorong tren akuntabilitas yang muncul dalam pelaporan CSR yaitu jaminan, pelaporan terintegrasi, kerangka kerja standar dan pedoman, dan regulasi. Meningkatnya permintaan pengungkapan kinerja CSR perusahaan menunjukkan bahwa kpelanggan, investor, pemerintah, dan lainnya menghargai informasi tersebut. Permintaan tersebut mungkin merupakan hasil dari kepedulian dan semangat yang tulus untuk masalah keberlanjutan atau sebagai sinyal investasi untuk kinerja perusahaan di masa depan. Jika pelaporan tidak kredibel dan hanya terkesan simbolis dari manajemen, penggunaan langkah-langkah non-keuangan ini dapat membuat asimetri informasi asimetri (Abernathy et al., 2017) dan (Silvestri \& Veltri, 2020).

Saat ini kinerja CSR dan kebijakan pelaporan tidak selalu selaras, pelaporan CSR lebih merupakan upaya pemasaran sebagai hasil kinerja CSR positif dalam keunggulan kompetitif perusahaan. Namun, jika pelaporan CSR bersifat simbolis dan tidak mewakili arah strategis perusahaan, terdapat potensi bahwa pelaporan tersebut tidak dapat dipercaya. Jika hal ini terus dilakukan reputasi perusahaan dapat rusak bahkan tidak dapat diperbaiki. Dengan demikian, pihak yang bertanggung jawab atas tata kelola harus diberi tahu tentang arahan, kinerja, dan pelaporan strategis CSR perusahaan. Perusahaan juga harus secara strategis menyelaraskan kinerja CSR mereka dengan kinerja keuangan (Hur et al., 2018) dan (Nejati et al., 2019).

Peran pemimpin dalam sifat matahari dan bintang terbentuk pada integrasi strategis kinerja dan transparansi dalam pelaporan CSR. Pemimpin bertugas memberi arahan penting bagi perusahaan untuk memenangkan hati pemerintah, pemangku kepentingan dan masyarakat. Permintaan pelaporan CSR adalah 
indikator utama bagi banyak pemangku kepentingan dan jika pelaporannya hanya sekedar simbolis dan tidak kredibel serta ditemukan hasil yang tifak memuaskan maka mungkin lebih merusak reputasi perusahaan.

Permintaan pelaporan CSR semakin meningkat, meskipun saat ini, perusahaan besar lebih cenderung melaporkan secara simbolis mengenai kinerja CSR. Pentingnya memberlakukan kebijakan CSR yang adil untuk semua perusahaan tidak hanya untuk perusahaan besar. Pemberlakuan kepatuhan bagi yang melanggar dan melaporkan metrik kinerja CSR . Seiring meningkatnya permintaan pelaporan CSR, demikian juga pentingnya kredibilitas informasi yang dilaporkan. Nilai pelaporan CSR berkurang jika perusahaan hanya menampilkan metrik kinerja CSR yang menguntungkan sedangkan untuk yang menimbulkan permasalahan tidak di ungkapan sehingga tidak secara akurat mencerminkan informasi kinerja CSR perusahaan. Peran pemimpin untuk tetap berpegang teguh pada keyakinan akan kinerja CSR yang maksimal dan dilaporkan secara transparan. Kinerja CSR perlu dilandasi dengan peran pemimpin yang etis dan menjadi sosok yang merangkul dan pemberi inspirasi bagi karyawan. Kinerja CSR yang sesuai norma dan etis akan menjadi pembeda dengan perusahaan lain meski sama-sama melakukan CSR, sehingga nilai perusahaan dimata pemangku kepentingan akan mengalami peningkatan. Kinerja CSR tidak luput dari kerjasama antara karyawan dengan pemimpin. Kenyamanan berkerja karyawan sumber kreatifitas kinerja CSR (Hemingway \& Starkey, 2018) dan (Reimer et al., 2018).

\section{SIMPULAN}

Penggunaan CSR memiliki tujuan untuk memberi pertanggung jawaban informasi atas aktivitas kepada seluruh pemangku kepentingan yang pada umumnya menjadikan laba dan tingkat kredibilitas perusahaan sebagai tujuan. Kritik atas pelaporan CSR tidak dapat menjadikan pedoman peranggung jawab perusahaan secara transparan menjadikan penelitian utama pada topik CSR. Peran pemimpin puncak menjadi penghubung eksternal antara pemangku kepentingan,pemerintah, dan masyarakat merupakan bukti konsisten dalam program keberlanjutan. Asta Brata dapat dijadikan pedoman ajaran secara nilai dan sikap etis pemimpin perusahaan pada kebijakan pembuatan program CSR. Asta Brata dianggap mampu menjawab fenomena yang mengenai pemimpin perusahaan membuat strategi atau peraturan program CSR akan tetapi masih sekedar simbolis dan tidak memiliki unsur etis dan peduli pada masalah sosial dan masyarakat. Asta Brata menjawab fenomena tersebut dari sisi sikap etis dan nilai-nilai norma yang harus diterapkan pada manajemen internal perusahaan.

Keterbatasan pada penelitian ini adalah sumber penelitian untuk menggali Asta Brata menggunakan literatur pustaka yang akan menimbulkan keterbatasan dalam penjabaran historis dan makna pada kehidupan sehari-hari setiap Asta Brata yang dikaitkan dengan kepemimpinan etis CSR. Literatur Pustaka yang digunakan memilki banyak macam pengertian yang berbeda satu sama lain. Hal tersebut membuat arti secara harfiah dan nilai-nilai yang terkandung pada Asta Brata dikembangkan oleh penulis dengan terbatas. Saran untuk penelitian berikutnya adalah perlu dilakukan wawancara secara 
mendalam pada orang yang memiliki ilmu yang memahami historis akan Asta Brata.

\section{REFERENSI}

Abernathy, J., Stefaniak, C., Wilkins, A., \& Olson, J. (2017). Literature review and research opportunities on credibility of corporate social responsibility reporting. American Journal of Business, 32(1), 24-41. https:// doi.org/10.1108/ajb-04-2016-0013

Anggoro, W. J., \& Virdanianty, M. (2015). Studi Eksplorasi Konstrak Kepemimpinan Model Jawa: Asta Brata. Jurnal Psikologi, 38(2), 228-239. https://doi.org/10.22146/jpsi.7655

Galant, A., \& Cadez, S. (2017). Corporate social responsibility and financial performance relationship: A review of measurement approaches. Economic Research-Ekonomska Istrazivanja , 30(1), 676-693. https:// doi.org/10.1080/1331677X.2017.1313122

Gea, A. A. (2014). Integritas Personal dan Kepemimpinan Etis. Humaniora, 5(2), 950. https://doi.org/10.21512/humaniora.v5i2.3197

Haula, B., \& Nur, T. (2018). Konseptualisasi Metafora dalam Rubrik Opini Kompas Tahun 2018: Kajian Semantik Kognitif ( The Conceptualization of Metaphor in The Rubric of Opinion Kompas 2018: A Cognitive Semantic ). Mozaik Humaniora, 1(2), 149-156.

Hemingway, C. A., \& Starkey, K. (2018). A Falling of the Veils: Turning Points and Momentous Turning Points in Leadership and the Creation of CSR. Journal of Business Ethics, 151(4), 875-890. https://doi.org/10.1007/s10551017-3659-3

Hur, W. M., Moon, T. W., \& Ko, S. H. (2018). How Employees' Perceptions of CSR Increase Employee Creativity: Mediating Mechanisms of Compassion at Work and Intrinsic Motivation. Journal of Business Ethics, 153(3), 629-644. https:// doi.org/10.1007/s10551-016-3321-5

Kalbarini, Y. R., \& Suprayogi, N. (2014). Implementasi Akuntabilitas Dalam Konsep Metafora Amanah Di Lembaga Bisnis Syariah (Studi Kasus: Swalayan Pamella Yogyakarta). JESTT (Jurnal Ekonomi Syariah Teori Dan Terapan, 1(7), 506-517.

Karaosmanoglu, E., Altinigne, N., \& Isiksal, D. G. (2016). CSR motivation and customer extra-role behavior: Moderation of ethical corporate identity. Journal of Business Research, 69(10), 4161-4167. https:// doi.org/10.1016/j.jbusres.2016.03.035

Kobalen, A. S., \& Bakti, A. F. (2019). Good clean governance (GCG) dalam kepemimpinan Basuki Tjahaja Purnama (Ahok) sebagai Gubernur DKI Jakarta ditinjau dari perspektif asta brata. Publisia: Jurnal Ilmu Administrasi Publik, 4(1), 81-102. https:// doi.org/10.26905/pjiap.v4i1.2272

Koten, Y. K. (2016). Hannah Arendt dan Etika Keduniawian. Diskursus - Jurnal $\begin{array}{lllll}\text { Filsafat Dan Teologi Stf Driyarkara, 15(2), } & 167 .\end{array}$ https:// doi.org/10.26551/diskursus.v15i2.10

Kövecses, Z. (2017). Conceptual metaphor theory. The Routledge Handbook of Metaphor and Language, 13-27.

Lee-Davies, L. (2018). Ethical CSR Leadership. International Journal of Sustainable 
Entrepreneurship and Corporate Social Responsibility, 2(2), 1-22. https://doi.org/10.4018/ijsecsr.2017070101

Maulidiana, L. (2018). Pengaturan csr menuju pembangunan berkelanjutan.

Nejati, M., Salamzadeh, Y., \& Loke, C. K. (2019). Can ethical leaders drive employees' CSR engagement? Social Responsibility Journal, 16(5), 655-669. https:// doi.org/10.1108/SRJ-11-2018-0298

Perrez, J., \& Reuchamps, M. (2015). Special issue on the political impact of metaphors. Metaphor and the Social World, 5, 165.

Phillips, S., Thai, V. V., \& Halim, Z. (2019). Airline Value Chain Capabilities and CSR Performance: The Connection Between CSR Leadership and CSR Culture with CSR Performance, Customer Satisfaction and Financial Performance. Asian Journal of Shipping and Logistics, 35(1), 30-40. https:// doi.org/10.1016/j.ajsl.2019.03.005

Rai, I. B., \& Suarningsih, N. M. (2019). Konsepsi Asta Brata dalam Kepemimpinan berlandaskan Tri Hita Karana. Jurnal Kajian Pendidikan Widya Accarya, 1(1), $1-6$.

Ratna, N. K. (2019). Metodologi penelitian kajian budaya dan ilmu sosial humaniora pada umumnya.

Reimer, M., Van Doorn, S., \& Heyden, M. L. M. (2018). Unpacking Functional Experience Complementarities in Senior Leaders' Influences on CSR Strategy: A CEO-Top Management Team Approach. Journal of Business Ethics, 151(4), 977-995. https:/ / doi.org/10.1007/s10551-017-3657-5

Rokhlinasari, S. (2016). Teori-teori dalam Pengungkapan Informasi Corporate Social Responbility Perbankan. Al-Amwal: Jurnal Ekonomi Dan Perbankan Syari'ah, 7(1).

Sahib, H. M. (2016). Sistem Anti fraud berbasis Metafora "Ronda" Suatu usulan untuk Indonesia.

Selvarajah, C., Meyer, D., Roostika, R., \& Sukunesan, S. (2017). Exploring managerial leadership in Javanese (Indonesia) organisations: engaging Asta Brata, the eight principles of Javanese statesmanship. Asia Pacific Business Review, 23(3), 373-395. https://doi.org/10.1080/13602381.2016.1213494

Setiyadi, I., \& Rasmini, N. (2016). Pengaruh Gaya Kepemimpinan, Komitmen Organisasi, Dan Pemahaman Sistem Informasi Akuntansi Pada Kinerja Auditor Kantor Akuntan Publik. E-Jurnal Akuntansi, 17(3), 1953-1980.

Silvestri, A., \& Veltri, S. (2020). Exploring the relationships between corporate social responsibility, leadership, and sustainable entrepreneurship theories: A conceptual framework. Corporate Social Responsibility and Environmental Management, 27(2), 585-594. https://doi.org/10.1002/csr.1822

Suchman, M. C. (1995). Managing legitimacy: Strategic and institutional approaches. Academy of Management Review, 20(3), 571-610.

Waniak-Michalak, H., Macuda, M., \& Krasodomska, J. (2016). Corporate Social Responsibility and Accounting in Poland: A Literature Review. Journal of Accounting and Management Information Systems, 15(2), 255-303.

Wibowo, S., Yokhebed, \& Tampubolon, L. D. (2016). Pengaruh csr disclosure dan gcg terhadap nilai perusahaan dengan kinerja keuangan sebagai variabel intervening di perusahaan manufaktur yang terdaftar di bursa efek indonesia (2012-2014). Prosiding Seminar Nasional Multi Disiplin Ilmu E Call 
For Papers Unisbank (Sendi_U) KE-2, 926-935.

Wijaya, D. N. (2016). Kontrak Sosial Menurut Thomas Hobbes dan John Locke. Jurnal Sosiologi Pendidikan Humanis, 1(2), 183-193.

Yuda, T. K. (2016). Memaknai Ulang Corporate Social Responsibility: Upaya Mewujudkan Fair Responsibility. Jurnal Ilmu Sosial Dan Ilmu Politik, 19(3), 200. https://doi.org/10.22146/jsp.15680 